\title{
PROSPECT PRODUKSI PRA SAPIH ANAK KAMBING HASIL SILANG KAMBING PE DENGAN KAMBING BOER
}

\section{(Prospect of Pre Weaning Production of Crossed Goat between PE Goat with Boer Goats)}

\author{
Lalu Ahmad Zaenuri ${ }^{1}$, Lukman $\mathrm{HY}^{2}$, Oscar Yanuarianto ${ }^{3}$ \\ ${ }^{1,2}$ ) Laboratorium Reproduksi Ternak dan ${ }^{3)}$ Laboratorium Nutrisi Ternak, Fakultas Peternakan, \\ Universitas Mataram, Jl. Majapahit No. 62 Mataram. Lombok, \\ Nusa Tenggara Barat, Indonesia, 83125 \\ *corresponding author,email: ahmadzaenuri@unram.ac.id
}

Manuscript received: 03-11-2018. Accepted: 08-12-2018

\begin{abstract}
ABSTRAK.
Penelitian bertujuan untuk mengetahui prospek produksi pra sapih hasil persilangan kambing PE dengan kambing Boer. Penelitian menggunakan 20 ekor induk kambing PE berat dan skor kondisi badan berturut-turut $39.35 \mathrm{~kg}$ dan 3. Pakan tunggal berupa daun turi diberikan dua kali sehari pagi dan sore secara ad libitum. Induk disinkronisasi birahi menggunakan $2 \mathrm{ml}$ Capriglandin secara intra muscular dan diinseminasi fix time 48-52 jam setelah injeksi Capriglandin. Induk yang tidak bunting dibiarkan kawin alam. Data lama bunting, berat lahir, pertambahan berat badan bulanan dan harian, sesuai tipe kelahiran, ditabulasi dan dihitung Mean \pm SE, diinterpretasi serta dijelaskan secara deskriptif. Hasil penelitian ini menunjukkan bahwa, dari 20 induk 18 diantaranya beranak 34 ekor terdiri dari 6 ekor tunggal jantan (TJ), 12 ekor tunggal betina (TB), 8 ekor kembar jantan (KJ), 2 ekor kembar betina (KB) dan 6 ekor kembar jantan-betina (KJB). Lama Bunting (hari) anak kambing TJ dan $(152 \pm 0.47) \mathrm{KJ}(152 \pm 2,00)$ atau lebih lama dibanding TB, KB dan kembar JB yaitu berturut-turut $149 \pm 3,82 ; 150 \pm 3,94 ; 147 \pm 2,94$. Berat lahir (kg) tertinggi yaitu TJ $(4,27 \pm 0,29)$ diikuti, TB $(3,52 \pm 0,27), \mathrm{KJ}(2,97 \pm 0,44), \mathrm{KB}(2,73 \pm 0,23)$ dan $\mathrm{KJJ}(2,71 \pm 0,54)$. Rataan ADG tertinggi pada umur 0-30 hari yaitu 201,33 gr/hari pada KJ jantan dan terendah 137,33 gr/hari pada KB. Disimpulkan, anak kambing hasil silang kambing Boer dengan PE sangat potensial sebagai calon stockbreeder kambing dwi fungsi.
\end{abstract}

Kata kunci: bibit, pertambahan berat harian, bunting, berat lahir

\begin{abstract}
.
The study aims to evaluate the pre-weaning production prospectus kids of PE crossed with Boer buck. Twenty PE does were in the average $39.35 \mathrm{~kg}$ body weight and 3 in body condition score. Does were offered single feed sesbandia glandiflora leaves twice a day. All does were synchronized by $2 \mathrm{ml}$ Capriglandin, inseminate fix time at 48-52 hours following Capriglandin injection. If the does were return to estrus following AI, then they were allowed natural mating. Data collected included gestation period, birth weight and average daily gain (ADG), tabulated and calculated for Mean $\pm \mathrm{SD}$, interpreted and explained descriptively. The number of kid were 34 consisting of 6 singles male (SM), 12 single female (SF), 8 male twin (MT), 2 female twins (FT) and 6 male-female twins (MFT).
\end{abstract}


Gestation period (days) were $152 \pm 0.47$ and $152 \pm 2.00$ for SM and MT. Shorten gestation period were noted for SF, FT and MFT (149 $\pm 3.82 ; 150 \pm 3.94$ and 147 \pm 2.94 , respectively). The highest birth weight $(\mathrm{kg})$ was SM $(4.27 \pm 0.29)$ followed by SF $(3.52 \pm 0.27)$, MFT $(2.97 \pm 0.44)$, FT $(2.73 \pm 0.23)$ and MT (2.71 \pm 0.54$)$. The highest ADG (gr/day) occurred at 0-30 days was in MT (201.33 g/d) and the lowest was in FT (137.33 g/d). In conclusion, crossbreeding kid of PE VS Boer goat has a high prospectus as dual purpose stockbreeder.

Key words: stockbreeder, daily gain, gestation, birth weight

\section{PENDAHULUAN}

Ada dua tujuan utama pengembangan ternak ruminansia yaitu untuk meningkatkan produksi daging dan susu. Meningkatkan kedua produksi ternak tersebut dilakukan untuk memenuhi kebutuhan masyarakat yang selalu meningkat dari waktu ke waktu akibat meningkatnya jumlah penduduk dan kesadaran masyarakat untuk mengkonsumsi protein asal ternak. Konsumsi daging per kapita pada tahun 2010 sebanyak 2,55 gram meningkat menjadi 2,92 gram dan 3,41 gram per hari pada tahun 2011 dan 2012 (Badan Pusat Statistik, 2013). Akibatnya, import daging dari tahun ke tahun harus dilakukan.

Untuk mengantisipasi kebutuhan daging yang selalu meningkat dari tahun ke tahun, pemerintah mendorong peran serta masyarakat untuk selalu terlibat secara aktif didalam membangun sumber daya peternakan seperti yang tertuang di dalam pedoman umum Program Swasembada Daging Sapi (PSDS). Didalam pedoman umum PSDS tahun 2014 dijelaskan bahwa, keberhasilan program swasembada daging sapi sangat tergantung kepada partisipasi penuh masyarakat peternak sapi potong, sehingga bagaimanapun baiknya program yang disusun tidak akan berhasil tanpa partisipasi masyarakat peternak dan para pelaku peternakan ternak potong lainnya (Permentan, N0. 19/Permentan/OT.140/2/2010). Salah satu jenis ternak yang memiliki potensi untuk mensubstitusi sebagian peran sapi dalam menyediakan daging, adalah ternak kambing dengan sebagai berikut:

Pertama, kambing dengan prospektus produksi yang tinggi dan pupuler di Indonesia yaitu kambing Peranakan Ettawah (PE) dan akhir-akhir ini kambing Boer. Kedua, kambing PE memiliki keunggulan tersendiri, PE jantan beratnya antara 68-91 kg, berat karkasnya antara 44-45\% dengan tingi badan antara 91-127 cm, sedangkan induk mampu menghasilkan susu rata-rata 3,8 kg per hari atau sekitar $588 \mathrm{~kg}$ selama masa laktasi dengan kadar lemak sekitar 5.2\%. (Devendra dan Burns, 1983). Demikian juga kambing Boer, produksi air susu induk yang sedang laktasi antara 1,3 - 1,8 kg per hari (Skinner, 1973; Devendra dan McLeroy, 1982; Devendra, 1994) dengan rataan produksi susu $160 \mathrm{~kg}$ selama 120 hari periode laktasi. Lu (2006) menjelaskan, masa laktasi untuk kambing tipe pedaging lebih pendek dibanding kambing tipe perah. Tetapi produksi susu kambing Boer (Ratts et al., 1983) selama 12 minggu masa laktasi berkisar antara 1.8-2.5 kg/hari dengan kandungan lemak susu 6.4-9.4\%, protein 3.0-4.5\% dan laktose 4.6-4.9\%. Belakangan, Tambajong et al. (2000) melaporkan bahwa, produksi susu kambing berkisar antara 1.9-2.23 kg/hari dengan kandungan lemak $3.4-4.6 \%$, protein $3.7-4.7 \%$, laktose $5.3-5.4 \%$ selama 8 minggu pertama masa laktasi.

Oleh karena itu, perlu upaya untuk memaksimalkan produktifitas kambing lokal sehingga perannya dalam menyediakan daging dan susu segar terus meningkat. Salah satu strategi untuk meningkatkan produktifitas ternak adalah meningkatkan mutu genetik melalui 
kawin silang karena, lebih fisibel dan keuntungan jangka panjangnya lebih besar dibandingkan dengan usaha mengubah lingkungan ternak melalui perbaikan nutrisi (Cunningham, 1991; Baker, 1994). Oleh karena itu, penelitian ini telah dilaksanakan dengan tujuan utama untuk mengetahui prospek produksi pra sapih anak kambing hasil silang kambing PE dengan kambing Boer sebagai calon stockbreeder kambing dwi fungsi.

\section{BAHAN DAN METODE}

\section{Lokasi dan waktu Penelitian}

Penelitian ini telah dilaksanakan di Kelompok Peternak "Kembang Turi" Desa Batujai, Kecamatan Praya Barat, Kabupaten Lombok Tengah. Penelitian dilaksanakan selama kurang lebih 11 bulan dengan alokasi waktu : Pra penelitian 2 bulan, masa bunting 5 bulan dan pengumpulan data pra-sapih selama 4 bulan.

\section{Persiapan ternak}

Penelitian menggunakan 20 ekor induk kambing PE betina yang sudah dipastikan tidak dalam keadaan bunting. Berat badan berkisar antara 37,9 - 40,7 kg, paritas 1-2, skor kondisi badan 3 dan umur 2,5-3 tahun. Pakan diberikan secara ad libitum 2 kali sehari yaitu pagi dan sore hari berupa pakan tunggal yaitu daun turi. Air minum diberikan satu kali sehari yaitu pada siang hari.

Persiapan penelitian meliputi, monitoring dan evaluasi status fisiologis ternak yaitu positip tidak dalam keadaan bunting. Perawatan kesehatan ternak, yaitu ternak harus terbebas dari internal dan external parasit. Evaluasi kondisi ternak, yaitu skor kondisi badan minimal 3 dan paritas minimal 1 .

\section{Sinkronisasi Birahi dan Inseminasi}

Sinkronisasi birahi dilakukan menggunakan hormon prostaglandin F2 $\alpha$ (Capriglandin ${ }^{\mathrm{TM}}$, Norbrook Laboratories Limited, Newry, Co. Down, Northern Ireland), injeksi intra muscular $2 \mathrm{ml} /$ ekor. Inseminasi dilakukan secara fix time 48 - 50 jam setelah sinkronisasi dan diulangi 4-6 jam kemudian (Greyling dan van den Nest, 2000) menggunakan semen beku kambing Boer yang dibeli di BIB Banyumulek, NTB. Deposisi semen dilakukan pada mulut servik bagian luar (os cervic externa). Untuk memastikan semua induk kambing bunting maka, jika ada induk kambing yang sudah diinseminasi menunjukkan gejala birahi kembali, ternak tersebut dibiarkan kawin alam dengan pejantan kambing Boer yang disewa dari PT. Sedhana Arif Nusa, Lombok Tengah, NTB.

\section{Pengambilan dan analisa data}

Data yang diambil meliputi lama bunting, berat lahir, tipe kelahiran serta pertambahan berat badan pra-sapih. Lama bunting dihitung berdasarkan jarak antara kawin sampai beranak. Berat lahir sesuai jenis kelamin dan tipe kelahiran dilakukan maksimal 24 jam setelah anak kambing tersebut lahir. Pertambahan berat badan anak kambing diukur setiap bulan selama pra sapih atau sampai umur 3 bulan. Data yang diperoleh ditabulasi dan dihitung ninai rata-ratanya dan standar errornya,selanjutnya diuraikan secara diskriptif. 


\section{HASIL DAN PEMBAHASAN}

\section{Litter size}

Delapan Belas ekor dari 20 ekor induk kambing yang digunakan untuk penelitian ini berhasil bunting dan beranak. Dari 18 ekor yang berhasil bunting dan beranak, 12 ekor diantaranya adalah hasil Insemnasi Buatan (IB), sedangkan 6 ekor sisanya adalah hasil kawin alam. Anak kambing yang lahir baik dari hasil IB maupun kawin alam tidak dibedakan, karena pejantan yang digunakan adalah sama yaitu kambing Boer. Jumlah anak seluruhnya adalah 36 ekor terdiri dari tipe kelahiran tunggal jantan 3 pasang (TJ), Tunggal betina (TB) 6 pasang, kembar jantan (KJ) 4 pasang, kembar betina (KB) 2 pasang dan kembar jantan betina (KJB) 3 pasang. Dari data tipe kelahiran (Tabel 1) diketahui bahwa sebaran data anak kambing tidak sama untuk setiap tipe kelahiran, tetapi data yang diperoleh dari hasil penelitian ini diharapkan dapat memberikan gambaran awal prospektus pproduksi anak kambing pra-sapih hasil persilangan kambing PE (betina) dengan kambing Boer (jantan).

Tabel 1. Hubungan antara tipe kelahiran dengan lama bunting, berat lahir anak kambing hasil silang kambing PE dengan kambing Boer.

\begin{tabular}{lcc}
\hline $\begin{array}{l}\text { Tipe } \\
\text { Kelahiran }\end{array}$ & $\begin{array}{c}\text { Lama Bunting } \\
\text { (Hari) }\end{array}$ & $\begin{array}{c}\text { Berat Lahir } \\
(\mathrm{kg})\end{array}$ \\
\hline Tunggal & & \\
Jantan $(\mathrm{n}=3)$ & $152 \pm 0,47$ & $4,27 \pm 0,29$ \\
Betina (n=6) & $149 \pm 3,82$ & $3.52 \pm 0,27$ \\
Kembar & & \\
Jantan-jantan (n=4) & $150 \pm 3,94$ & $2.71 \pm 0,54$ \\
Betina-betina (2) & $152 \pm 2,00$ & $2.73 \pm 0,23$ \\
Jantan-betina (3) & $147 \pm 2,94$ & $2,97 \pm 0,44$ \\
\hline Sumber: Data hasil penelitian (2017) & &
\end{tabular}

Sumber: Data hasil penelitian (2017)

Rata-rata Litter size hasil penelitian ini adalah 2. Campbell (2003) melaporkan, hampir 50-60\% kambing Boer beranak kembar dua dan 10-15\% lainnya beranak kembar tiga. Kambing adalah ternak yang sangat prolifik sehingga sering dijumpai seekor induk mampu menghasilkan anak kembar 5 (Zaenuri, 2005; Zaenuri dan Rodiah, 2017).

\section{Lama bunting}

Lama bunting untuk anak kambing TJ dan KB cendrung lebih lama dibanding tipe kalahiran yang lain. Kisaran lama bunting hasil penelitian ini yaitu antara $147 \pm 2,94-$ $152 \pm 2,00$ hari. Lama bunting untuk tipe kelahiran tunggal jantan dan betina (Tabel 1) berturut-turut $152 \pm 0,47$ dan $149 \pm 3,82$. Mahmilia et al. (2008) melaporkan, lama bunting kambing kacang (betina) yang disilanggkan dengan kambing Boer (jantan) untuk tipe kelahiran tunggal jantan dan tunggal betina berturut-turut 148,32 $\pm 3,05$ dan 147,53 $\pm 2,95$. Lama bunting induk kambing PE yang disilangkan dengan kambing Boer adalah 159,31 44,37 hari (Adhianto et al., 2012). Selain itu kambingjuuga sangat responsif terhadap perlakuan penyerentakan birahi (Zaenuri et al., 2016). 
Rataan lama bunting pada kelahiran kembar dua lebih singkat $(146,85 \pm 2,83$ hari) dibandingkan dengan kelahiran tunggal yaitu 148,79 $\pm 2,89$ hari (Mahmilia et al., 2008). Hasil yang hampir sama dilaporkan oleh Artiningsih et al. (1996), yaitu 145,5 $\pm 2,10$ hari dan $149,0 \pm 2,70$ hari. Selanjutnya Setiadi et al. (2001) menyatakan bahwa semakin banyak jumlah anak yang dikandung, lama bunting cendrung lebih singkat. Partus pada kelahiran tunggal terjadi dengan rentang waktu yang lebih panjang (144 sampai 158 hari), dimana persentase tertinggi $(16,90 \%)$ terjadi pada lama bunting 150 hari. Sedangkan partus pada kelahiran kembar 2 terjadi dengan rentang waktu yang lebih singkat (142 sampai 151 hari), dan persentase terbanyak $(29,62 \%)$ terjadi saat lama bunting 148 hari. Hasil penelitian ini mendapatkan partus terjadi pada kisaran umur fetus 142 sampai 158 hari. Berbeda dengan yang didapat Sutama (2004) yaitu berkisar antara 147-155 hari. Devendra dan Burn (1994) menjelaskan, penyebab keragaman tersebut dipengaruhi oleh musim, lingkungan, pejantan yang digunakan dan interaksi diantaranya. Greyling dan van Niekerk (1986) menjelaskan, lama bunting kambing Boer rata-rata adalah 148 hari dan ada kecendrungan lama bunting induk kambing beranak kembar lebih pendek 1 sampai 2 hari dibanding kambing beranak kembar tiga

\section{Berat lahir dan pertumbuhan pra-sapih}

Ada kecendrungan bahwa anak kambing yang lahir tunggal jantan maupun tunggal betina berat lahirnya lebih tinggi dibanding anak kembar (Tabel 2). Hal ini disebabkan tidak ada kompetisi suplay nutrisi dari induknya serta jumlah dan kualitas pakan yang diberikan. Untuk penelitian ini, pakan yang diberikan, khususnya selama trimester terakhir masa buntnig dan selama tiga bulan masa laktasi adalah pakan tunggal berupa daun turi. Mahmilia et al. (2008) melaporkan berat lahir kembar dua anak kambing hasil persilangan kambing

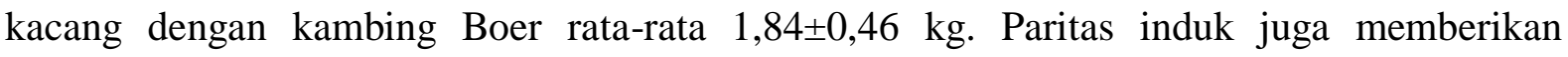
pengaruh terhadap bobot lahir anaknya. Paritas induk kambing PE yang digunakan untuk penelitian ini adalah 2-3. Mahmilia et al. (2008) melaporkan, berat lahir anak dari induk dengan paritas dua lebih tinggi dibbanding berat lahir anak dari induk dengan paritas satu.

Tabel 2. Tipe kelahiran dan berat badan pra sapih anak kambing hasil silang kambing PE (betina) dengan kambing Boer (jantan).

\begin{tabular}{|c|c|c|c|}
\hline \multirow{2}{*}{$\begin{array}{c}\text { Tipe } \\
\text { Kelahiran }\end{array}$} & \multicolumn{3}{|c|}{ Umur (Hari) dan Berat Badan (kg) } \\
\hline & 30 & 60 & 90 \\
\hline \multicolumn{4}{|l|}{ Tunggal } \\
\hline Jantan $(n=3)$ & $8,57 \pm 0,12$ & $10,20 \pm 1,02$ & $12,33 \pm 0,53$ \\
\hline Betina $(n=6)$ & $7,63 \pm 0,72$ & $10,80 \pm 1,72$ & $12,23 \pm 1,63$ \\
\hline \multicolumn{4}{|l|}{ Kembar } \\
\hline Jantan-jantan $(n=4)$ & $7,85 \pm 1,03$ & $9,78 \pm 1,31$ & $12,25 \pm 1,06$ \\
\hline Betina-betina (2) & $5,35 \pm 0,95$ & $6,35 \pm 1,15$ & $7,68 \pm 1,58$ \\
\hline Jantan-betina (3) & $7,15 \pm 2,15$ & $8,65 \pm 2,87$ & $9,87 \pm 2,38$ \\
\hline
\end{tabular}


Bobot lahir pada kelahiran kembar cendrung lebih rendah dibanding kelahiran tunggal disebabkan karena kompetisi dalam menyerap makanan dari induknya selama pertumbuhan embrio dalam uterus, sedangkan anak yang dilahirkan tunggal dapat menyerap nutrisi secara maksimal dari induknya (Atkins dan Gilmour, 1981). Berat lahir anak kambing Boer (full blood) berkisar antara 3-4 kg dimana anak kambing jantan 0,5 kg lebih berat dibanding betina.rata (Lu dan Potcoiba, 1988).

\section{Pertambahan Bobot Badan Harian}

Rata-rata pertambahan berat badan harian (ADG) tertinggi hasil penelitian ini terjadi pada umur 0-30 hari yaitu 201,33 gr/hari pada anak kembar jantan dan terendah 137,33 pada kembar betina. Selanjutnya pertambahan berat badan harian akan menurun sesuai dengan pertambahan umurnya (Grafik 1).

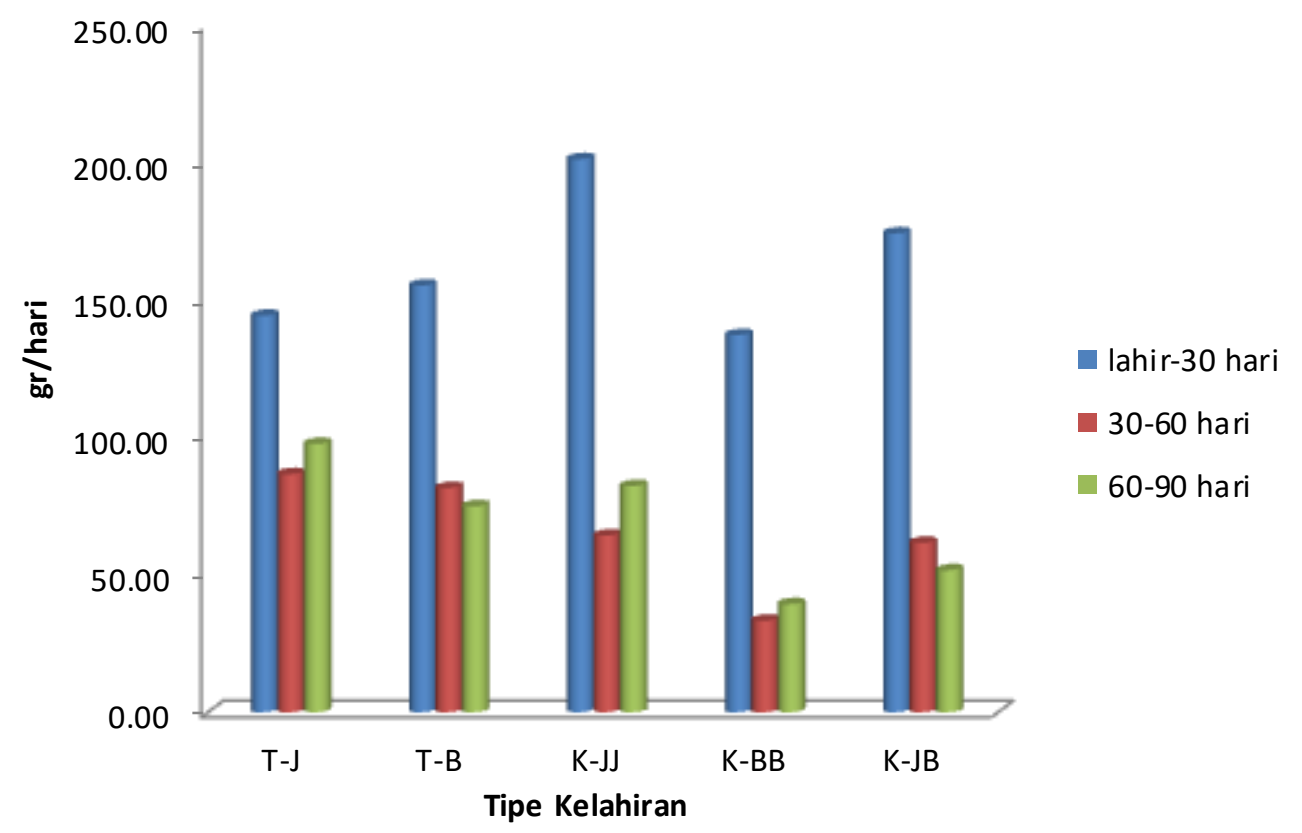

Grafik 1. Pertambahan berat badan sejak lahir-30 hari, 30-60 dan 60 - 90 hari untuk tipe kelahiran Tunggal Jantan (T-J), Tunggal betina (T-B), Kembar jantan-jantan (K-JJ), kember betina-betina (K-BB) dan kembar jantan-betina (K-JB)

Tidak jauh beda dengan hasil penelitian ini, ADG anak kambing Boer (full blood) adalah 62, 139, 182, dan $194 \mathrm{~g}$ berturut-turut untuk pertambahan berat sejak lahir-10 kg, 10$23 \mathrm{~kg}, 23-32 \mathrm{~kg}$, dan 32-41 kg berat badan (Lu dan Potcoiba, 1988). Kambing Boer dikenal memiliki tingkat pertumbuhan lebih cepat dibandingkan dengan jenis kambing lainnya. Jika kualitas pakannya baik, tingkat pertumbuhan selama 12 bulan pertama bisa mencapai ratarata 200 g/ekor/ hari. Rata-rata tingkat pertumbuhan sesuai umurnya adalah 291, 272, 245, dan 250 g/hari dari lahir sampai 100, 150, 210, dan 270 hari pada kambing jantan dan 272, 240, 204, dan 186 g/hari pada kambing betina (Van Niekerk dan Casey , 1988).

Kambing kacang dengan pakan yang kualitas dan kuantitasnya cukup juga akan menunjukkan performan produksinya yang maksimal. Dahlanuddin et al. (2003) melaporkan, 
ADG anak kambing kacang yang induknya diberikan pakan $100 \%$ daun turi dua kali lipat yaitu 105 $\pm 4,7 \mathrm{~g} /$ hari (tunggal) dan 92 \pm 7,9 g/hari (kembar) dibanding ADG anak kambing kacang dengan pakan $100 \%$ rumput lapangan yang hanya $51 \pm 7,8 \mathrm{~g} /$ hari (tunggal) dan $41 \pm 6,4$ $\mathrm{g} /$ hari (kembar). Peneliti lain melaporkan, berat sapih kambing kacang dan kambing Boer berturut turut $10,2 \mathrm{~kg}$ dan $20,5 \mathrm{~kg}$ (Elisier et al., 2012). Dari uraian dan perbandingan berbagai hasil penelitian sejenis dengan penelitian ini, Hasil penelitian ini memberikan gambaran yang positip terhadap prospek anak kambig hasil persilangan kambing PE (betina) dengan kambing Boer (jantan) sebagai calon stockbreeder yang bisa dikembangkan menjadi kambing dwi fungsi, penghasil daging sekaligus penghasil susu yang produktif.

\section{KESIMPULAN DAN SARAN}

Anak kambing hasil persilangan kambing Boer dengan kambing PE (Boercross) yang diperoleh dari hasil penelitian ini menunjukkan prospektus produksi pra sapih yang cukup tinggi. Oleh karena itu, untuk jangka panjang diharapkan bisa menjadi stockbreeder awal kambing dwi guna karena merupakan hasil persilangan dua tipe kambing yang berbeda yaitu potong (kambing Boer) dengan kambing tipe perah (kambing PE).

Untuk mendapatkan stockbreeder yang benar-benar unggul dan siap disebarkan kepada peternak, disarankan supaya dilakukan uji adaptasi sampai beberapa generasi terhadap berbagai kondisi lingkungan yang berbeda.

\section{Ucapan Terima Kasih}

Terima kasih disampaikan kepada Kemenristek Dikti yang telah membiayai penelitian ini melalui skim penelitian Masterplan Percepatan dan Perluasan Pembangunan Ekonomi Indonesia 2011-2025 (PENPRINAS MP3EI 2011-2025) tahun anggaran 2016-2019

\section{DAFTAR PUSTAKA}

Adhianto, K., N. Ngadiyono, Kustantinah dan I.G.S. Budisatria. 2012. Lama Kebuntingan, Litter Size, dan Bobot Lahir Kambing Boerawa pada Pemeliharaan Perdesaan di Kecamatan Gisting Kabupaten Tanggamus. Jurnal Penelitian Pertanian Terapan Vol. 12 (2): 131-136.

Artiningsih, N.M., B. Purwantara, R.K. Achyadi dan I.K. Sutama. 1996. Pengaruh penyuntikan PMSG terhadap kelahiran kembar pada kambing dara PE. JITV 2: 11 16.

Atkins, K.D and A.R. Gilmour. 1981. The comparative productivity of five ewe breeds, 4. Growth and carcase characteristics of purebred and cossbreed lambs. Aust, J. Exp. Agr. Anim. Husb. 21: 172 - 178.

Barker, J.S.F. 1994. Animal breeding for tolerance to adverse environment. In Sustainable Animal Production and the Environment. Proceedings of the 7th AAAP Animal Science Congress. Bali, Indonesia. Vol. 1. pp.: 29-39.

BPS. 2013. Rata-rata Konsumsi Daging. Badan Pusat Statistik, Jakarta

Campbell, Q.P. 2003. The Origin and Description of Southern Africa's Indigenous Goats. Anim. Sci. 4:18-22.

Cunningham, E.P. 1991. Breeding program for improved dairy production in tropical climates. In Animal Husbandry in Warm Climates. Proceedings of the International 
Symposium on Animal Husbandry in Warm Climates. Viterbo, Italy. Pudoc Wageningen. pp.: 31-38. pp.: 39-47.

Dahlanuddin, L.A. Zaenuri, M. Muzani, Mashur, T.S. Panjaitan. 2003. Pengembangan model peternakan kambing berbasis tanaman turi. Laporan Penelitian. Kerjasama Fakultas Peternakan Unram dengan BPTP NTB.

Devendra, C dan M. Burns. 1994. Produksi Kambing di daerah Tropis. Institut Teknologi Bandung, Bandung.

Devendra C dan M. Burns. 1983. Goat production in the tropics. Common. Jur. Agric. Tech. No. $19: 39$.

Devendra C and G.B. McLeroy. 1982. Goat and sheep production in the Tropics. Logman, London and New York.

Direktorat Jenderal Peternakan. 2014. Buku Statistik Peternakan. Jakarta: Departemen Pertanian.

Elieser, S., G.S. Sumadi, I.G.S.Budisatria and Subandriyo. 2012. Productivity comparison between Boer and Kacang goat dam. J.Indonesian Trop.Anim.Agric. 37(1): 15-21.

Greyling, J.P.C and C.H. VanNiekerk. 1986. Sychronization of estrus in the Boer goatdoe: Does effect on prostaglandin in the double injection regime. S. Afr. J. Anim. Sci. 16:146150.

Lu, C.D and M.J. Potchoiba. 1988. Milk feeding and weaning of goat kids. Small Ruminant Research. 1:105-112.

Lu, C.D and M.J. Potchoiba. 1990. Feed intake and weight gain of growing goats fed diets of various energy and protein levels. J. Anim. Sci. 68:1751-1759. 